\title{
Identifying glacio-isostatic rebound processes using testate amoeba as palaeohydrological proxies; a case study from subarctic Québec, Canada
}

\author{
Crystal FERGUSON ${ }^{1}$, I. Florin PENDEA ${ }^{1}$ \\ ${ }^{1}$ Lakehead University, Sustainability Sciences Department, 500 University Avenue, Orillia, ON L3V0B9, \\ Canada
}

Received 20 November 2018; Revised 10 December 2018; Accepted 17 December 2018

*Correspondence to: I. Florin PENDEA e-mail: ifpendea@lakeheadu.ca

\begin{abstract}
Glacio-isostatic rebound is one of the most important landscape processes affecting the northern and northeastern coast of Canada and, therefore, reconstruction of postglacial rebound rates is critical for a better understanding of landscape evolution in this region. Yet, studies reconstructing coastal palaeogeography in Northern Canada are constrained by the limitation of shell-based radiocarbon chronologies used in dating shoreline displacement and palaeo-sea levels. This study proposes an alternative methodology for the reconstruction and dating of palaeo-sea levels, which uses testate amoeba microfossils from coastal sediments as palaeoecological markers of coastal water table shifts linked to sea level change. Our results indicate that testate amoeba-inferred water table reconstruction is a good indicator of water table drawdown due to isostatic uplift on affected coastlines. Furthermore, radiocarbon dating of distinct plant macrofossils within the transitional marine/freshwater stratigraphy avoids the inherent reservoir effect issues associated with dating of marine shells.
\end{abstract}

KEYWORDS

glacio-isostasy, wetland hydrology, paleoecology, testate amoebae, Transfer Function, radiocarbon dating

\section{Introduction}

The demise of the late Laurentide Ice Sheet during the early Holocene induced a large-scale process of isostatic rebound throughout northern and northeastern Canada. In the James Bay region, the postglacial isostatic rebound caused one of the highest vertical shoreline displacement known during the Holocene - more than 300 m in 8000 years (HillaireMarcel, 1980). Despite this dramatic reorganisation of coastal geomorphology, it is still unclear whether the isostatic rebound was a major driver of land- 
scape change beyond the immediate impact on costal configuration. One study conducted in the Hudson Bay Lowlands (Glaser et al., 2004) - a region adjacent to James Bay - found that differential rates of isostatic uplift across the region was the principle driver of peatland development and that fast rates of uplift result in continuous alteration of peatland hydrology. As land emerges and marine influence retreats, shoreline displacement drives water level decrease across the region. Other studies, such as Pendea (2011) and Pendea and Chmura (2012) found that isostatic rebound had a major impact on coastal ecology, but inland areas were less affected.

Regardless of the type of study undertaken, the quality of the scientific data related to glacio-isostatic processes hinges, to a large degree, on precise dating and reconstruction of transitional marine-terrestrial stratigraphies. Most previous studies on palaeo-sea levels have used fossil marine mollusc shells, driftwood and palaeosoils to date and reconstruct the position of former coastlines (e.g., Allard and Seguin, 1985; Lajeunesse and Allard, $2003 \mathrm{a}, \mathrm{b})$ or diatom-inferred salinity shifts linked to sea level change in coastal lakes (e.g., Saulnier-Talbot and Pienitz, 2001; Miousse et al., 2003, Fedje et al., 2018). Some of the limitations in these studies stem from the fact that marine shells are not an ideal material to use in radiocarbon dating due to the variable and difficult to constrain reservoir effect (e.g., Allard and Seguin, 1985; Lajeunesse and Allard, $2003 \mathrm{a}, \mathrm{b}$ ). Moreover, the use of marine shells to reconstruct palaeo-sea levels is further complicated by the fact that many of the molluscs commonly dated in the James/Hudson Bay region have wide ecological tolerances with respect to water depth (Aitken and Fournier, 1993) and thus they may be poor proxies for the position of sea levels.

In studies where the marine/terrestrial stratigraphies were reconstructed based on diatom assemblage from former coastal lakes (e.g., Saulnier-Talbot and Pienitz, 2001; Miousse et al., 2003, Fedje et al., 2018), there is likely a lag in the decline of coastal lake water salinity that may vary with the lake volume and whether or not the system is open or closed (Pendea et al., 2010). This lag time between the reduction in lake salinity and the actual local shoreline displacement can lead to an imprecise reconstruction of palaeo-sea levels.

In a more recent study, Pendea at al. (2010) used AMS radiocarbon dating of freshwater macrofossils from marine/terrestrial sedimentary transitions and analysis of pollen, spores, and dinoflagellate cysts to define the tidal stratigraphy - an ideal proxy for palaeo-sea levels. This study avoided many of the problems associated with imprecise dating of palaeo sea levels and demonstrated that palaeoecological proxies can be used to refine transitional stratigraphies.

In this study, we build on the findings of Pendea et al. (2010) and propose a methodology that provides direct evidence of water table drawdown due to isostatic uplift and better constrains the period of retreat of tidal influence. To this end, we use fossil testate amoebae assemblages from two sites in a depth-to-water table (DWT) transfer function to reconstruct coastal hydrology at the time of coastal emergence. We hypothesize that testate amoeba assemblages will indicate a sharp water table drawdown across the marine/terrestrial sedimentary interface as evidence for land uplift and retreat of tidal influence.

\section{Study site}

The study region (Fig. 1) is located in the high boreal zone of eastern James Bay, northwestern Québec (Canada). The region was covered by the last remnants of the Laurentide ice sheet until the early Holocene, after which marine waters from the Tyrell Sea began to flood the newly deglaciated surface (Dyke, 2004). The establishment of the marine stage was short, followed by shoreline regression under the influence of glacio-isostatic rebound. A progressive landscape emergence from east to west began 7000 years ago in the study region and is currently still underway (Pendea at al., 2010). The James Bay regional climate is continental subarctic and is part of the Perhumid High Boreal Eco-climatic Region where the mean January temperature is $-23^{\circ} \mathrm{C}$, mean July temperature is $14^{\circ} \mathrm{C}$, and the annual precipitation ranges between $528-833 \mathrm{~mm}$ (Crins et al., 2009). The regional vegetation consists of open boreal taiga, is dominated by stands of stunted Picea mariana with Pinus banksiana, Alnus 
spp., Larix larciana, and Betula glandulosa as secondary constituents, and is interspersed with open fens and bogs (Crins et al., 2009).

Site W55 $\left(53^{\circ} 1^{\prime} N, 78^{\circ} 10^{\prime} \mathrm{W}\right)$ is a bog situated about $55 \mathrm{~km}$ east of the town of Wemindji (Québec). The site has an elevation of $130 \mathrm{~m}$ a.s.l. and is surrounded by relatively steep slopes towards the south. An intermittent brook on the northern margin partially drains the site, but the overall drainage is poor due to the underlying marine clays. The peatland developed in a former cove on the northwest side of a newly emerged island after $6400 \mathrm{cal}$ yr BP (Pendea et al., 2010). The peatland vegetation at W55 site is dominated by Sphagnum mosses and ericaceous shrubs with patches of sedges and lichens. Stunted trees (Picea mariana) border the margins of the bog.

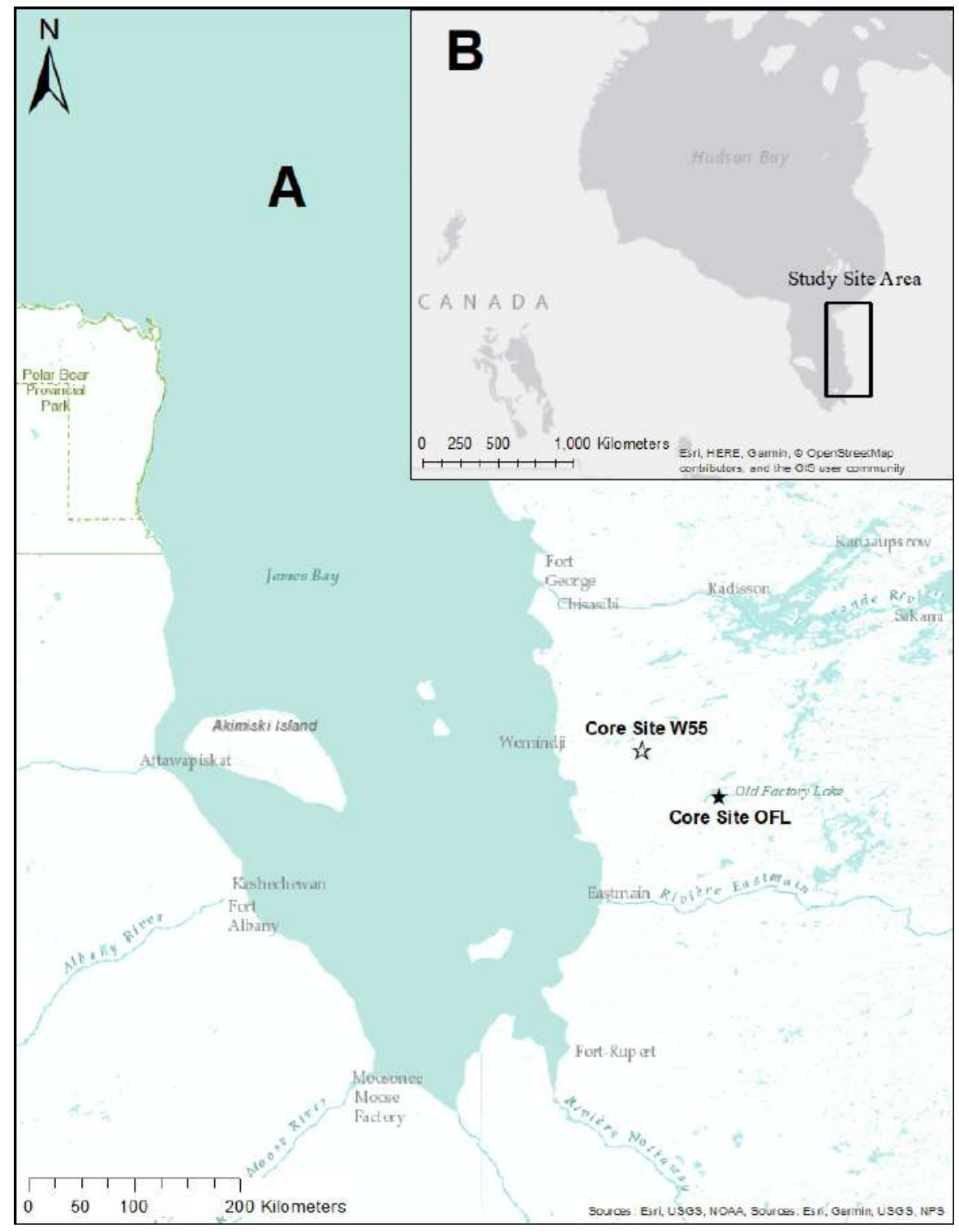

Figure 1 Location of the study region

Site OFL $\left(52^{\circ} 47^{\prime} N, 77^{\circ} 31^{\prime} \mathrm{W}\right)$ is a poor fen/bog complex situated on the southern shores of Old Factory Lake, approximately $110 \mathrm{~km}$ southeast from the town of Wemindji (Québec). The wetland has an elevation of $103 \mathrm{~m}$ a.s.l and is characterized by a flat topography with no surface drainage. The surface vegetation is dominated by Sphagnum and ericaceous shrubs along with stunted Picea mariana trees 
found isolated throughout the bog (Pendea, 2011). The peatland developed on a former tidal flat, which at the time of emergence was a large protected bay (Pendea et al., 2010). When the sea finally retreated, the former bay was replaced by the Old Factory Lake (Fig. 1). The local base level created by the Old Factory Lake is the primary control for the local water table level at this site. The subterraneous drainage is very poor due to the thick marine clay layer at its base.

\section{Materials and methods}

\subsection{Field and laboratory sampling}

To reconstruct the marine/terrestrial transition and the palaeohydrology of the two sites, we used five$\mathrm{cm}$ diameter cores extruded from the deepest part of each peatland with a $2 \mathrm{~m}$-long Eijkelkamp ${ }^{\circledR}$ piston corer. The top $0.5 \mathrm{~m}$ of the cores, containing Sphagnum peat with tough ericaceous root systems was cut with a knife. Cores were transported in PVC pipes and stored in a cold room at $4^{\circ} \mathrm{C}$ until subsampled in the laboratory. Cores were then sliced into 0.5 or $1 \mathrm{~cm}$-thick sections and from the center of each section a subsample was removed using a $1.5 \mathrm{~cm}$-diameter metal cylinder. Thinner sections were cut above and below the marine/terrestrial interface. Mean sampling resolution within the cores was $6 \pm 3 \mathrm{~cm}$ (180 $\pm 166 \mathrm{yrs})$ for the W55 core, $6 \mathrm{~cm}$ $\pm 2 \mathrm{~cm}(133 \pm 90 \mathrm{yrs})$ for OFL core. Core W55 had very low accumulation rates between 222 and 227 cm-depth.

\subsection{Dating and age-depth modelling}

Accelerated Mass Spectrometry (AMS) radiocarbon measurements were obtained exclusively on macrofossils including seeds, twigs, leaves, and Sphagnum stems and leaves (Table 1 and 2). AMS radiocarbon analysis was performed by Beta Analytic Inc. Quoted errors represent one relative standard deviation statistics (68\% probability) and counting errors are based on the combined measurements of the sample, background, and modern reference standards. Radiocarbon ages were corrected for isotopic fractionation and were calibrated using the INTCal13 curve (Reimer et al., 2004) and the calculations were performed using the cubic spline fit (Talma and Vogel, 1993). Calibrated ranges are reported as two standard deviations (Tables 1 and 2).

Table 1 Radiocarbon measurements and associated calendar ages based on macrofossils from OFL core James Bay, Québec

\begin{tabular}{|c|c|c|c|c|c|c|}
\hline \multirow{2}{*}{$\begin{array}{l}\text { Sample } \\
\text { Depth }(\mathrm{cm})\end{array}$} & \multirow[t]{2}{*}{ Dated material } & \multirow[t]{2}{*}{ Beta code } & \multirow{2}{*}{$\begin{array}{l}\text { Radiocarbon } \\
\text { age (yr BP) }\end{array}$} & \multicolumn{3}{|c|}{$2 \sigma$ probability CAL age (yr BP) } \\
\hline & & & & 1st & 2nd & Midpoint \\
\hline 204 & Sphagnum stems and leaves & 251801 & $3980 \pm 40$ & $4400-4530$ & & 4465 \\
\hline 225 & Alnus twig & 251802 & $4040 \pm 40$ & $4770-4790$ & $4420-4620$ & 4780 \\
\hline 233 & Alnus bark and twig & 251800 & $4320 \pm 40$ & $4970-4840$ & & 4905 \\
\hline 237 & $\begin{array}{l}\text { Charred material (seeds, } \\
\text { wood, and Picea needle) }\end{array}$ & 257586 & $4970 \pm 40$ & $5830-5860$ & $5600-5750$ & 5675 \\
\hline
\end{tabular}

Table 2 Radiocarbon measurements and associated calendar ages based on macrofossils from W55 core James Bay, Québec

\begin{tabular}{|c|c|c|c|c|c|c|}
\hline \multirow{2}{*}{$\begin{array}{l}\text { Sample } \\
\text { Depth (cm) }\end{array}$} & \multirow[t]{2}{*}{ Dated material } & \multirow{2}{*}{$\begin{array}{l}\text { Beta } \\
\text { code }\end{array}$} & \multirow{2}{*}{$\begin{array}{l}\text { Radiocarbon } \\
\text { age (yr BP) }\end{array}$} & \multicolumn{3}{|c|}{$2 \sigma$ probability CAL age (yr BP) } \\
\hline & & & & 1st & 2nd & Midpoint \\
\hline 208 & Alnus twig & 251807 & $3090 \pm 40$ & $3220-3390$ & & 3305 \\
\hline 221 & Alnus twig, Betula leaf & 251806 & $3930 \pm 40$ & $4510-4480$ & $4440-4250$ & 4345 \\
\hline 226 & Alnus twig & 251805 & $5630 \pm 40$ & $6490-6310$ & & 6400 \\
\hline
\end{tabular}


Age-depth models for cores OFL and W55 (Figs. 2 and 3) were derived using the Bayesian Bchron model as incorporated in the Bchron $\mathrm{R}$ software package (Haslett and Parnell, 2008; Parnell et al., 2008). This model outperforms other age-depth models, as shown by a large-scale experiment conducted on Holocene lake sediments (Parnell et al., 2008).

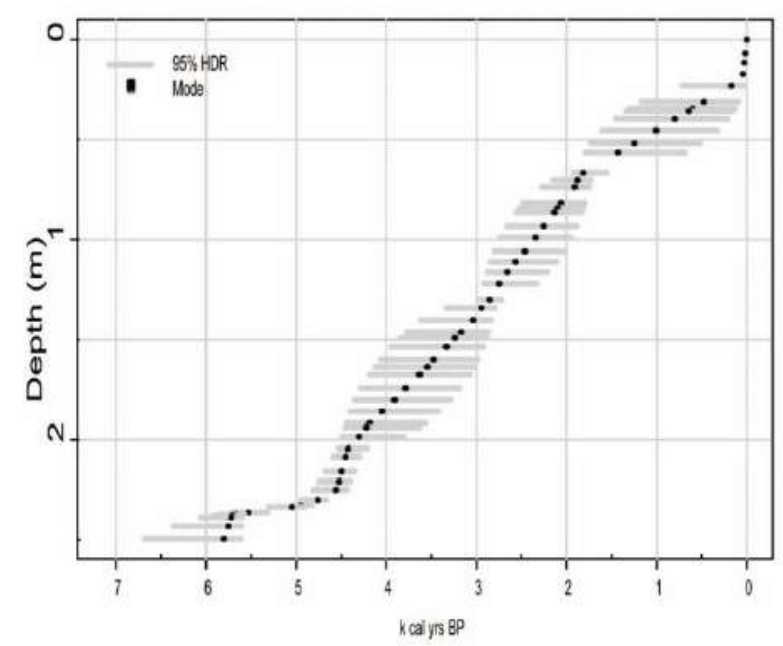

Figure 2 The age-depth model for core OFL based on radiocarbon dates as constructed by the Bchron software (Haslett and Parnell, 2008; Parnell et al., 2008). Grey bars represent the $95 \%$ confidence interval of calendar ages

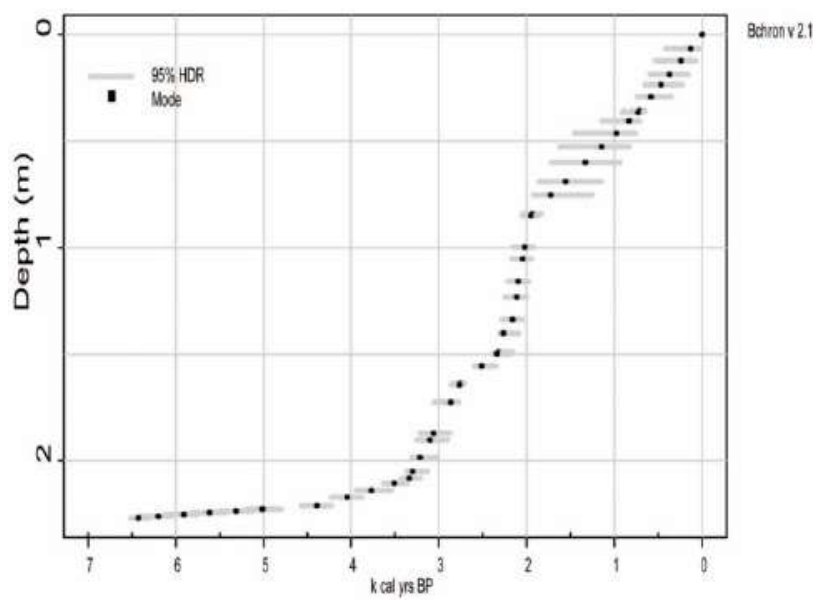

Figure 3 The age-depth model for core W55 based on radiocarbon dates as constructed by the Bchron software (Haslett and Parnell, 2008; Parnell et al., 2008). Grey bars represent the $95 \%$ confidence interval of calendar ages

\subsection{Testate Amoebae sample preparation}

Approximately $1.5 \mathrm{~cm}^{3}$ of peat material from the center of each $1-\mathrm{cm}$ thick slice was put in test tubes where a Lycopodium tablet of known spore number was added for calculation of test concentrations. The samples were then boiled in distilled water for 10 minutes followed by a two-part sieving process. The samples were passed through a 300- $\mu \mathrm{m}$ sieve and retained on a $15-\mu \mathrm{m}$ sieve after thorough washing. Samples were then centrifuged to remove excess water and mounted on slides for identification. All samples were counted to 150 specimens to increase randomness and decrease possibility of missing a species. The taxonomic framework and nomenclature follows Charman (2001) as modified by Booth (2007). Taxa identification was conducted using a key published by Booth and Sullivan (2007).

\subsection{Zonation}

All taxa were used to subdivide the testate amoebae assemblage diagrams into local testate assemblage zones (LTAZ) using constrained cluster analysis by sum-of-squares (CONISS) as implemented in the Psimpoll 4.27 program (Bennett, 2007). Only zones representing significant clusters according to the broken stick model (Bennett, 2007) were retained and each is presented in detail in the Results section.

\subsection{Depth-to-water-table transfer function}

In this study, we used testate amoeba analysis to reconstruct the long-term hydrological variability for the OFL and W55 peatlands, measured as depth-to-water table (DWT). Testate amoebae are protozoans that inhabit distinct ecological niches related to moisture conditions and produce morphologically distinct shells that can be used as palaeoecological indicators of hydrologic changes as they respond rapidly to changes in the hydrology (Mitchell et al., 2007).

These proxy indicators are particularly abundant in Sphagnum dominated peatlands. The distinct siliceous shells of testate amoebae preserve well in peat deposits making them complementary indicators to other long-established indicators such as pollen, spores and macrofossils (Mitchell et al., 2007). Authors such as Woodland (1998), Booth (2002, 2007), Booth and Zygmunt (2005), Booth et al. (2010), Booth and Sullivan (2007), Amesbury et al. (2013), Lamarre et al. (2013), and van Bellen et al. (2014) have studied the ecology of testate amoebae 
species and developed transfer functions from modern analogue data sets, which relate community species assemblages to mean annual water table depths. The transfer functions were then used in various peatland studies to infer current and past hydrology conditions.

Raw fossil test abundance data was transformed in percent relative abundance for each core. A transfer function was developed with the assistance of Dr. Robert K. Booth from Lehigh University using the weighted average partial least square (WA-PLS) model (Booth, 2008). The WA-PLS model returns the smallest DWT errors although the general performance is similar to that of other commonly used models, such as weighted averaging (WA), weighted averaging with tolerance downweighting (WA-Tol), and weighted modern analogue technique (WMAT). The modern analogue dataset $(n=650)$ is based on testate amoebae species-environment relationships from 369 sites across North America (Booth, 2008). The transfer function model was applied to our fossil dataset using the C2 software (Juggins, 2003; Booth, 2008) and mean water-table-depth was inferred with a mean error of 6-8 cm (Booth, 2008).

OFL core, Testate amoeba assemblages, James Bay, Qc

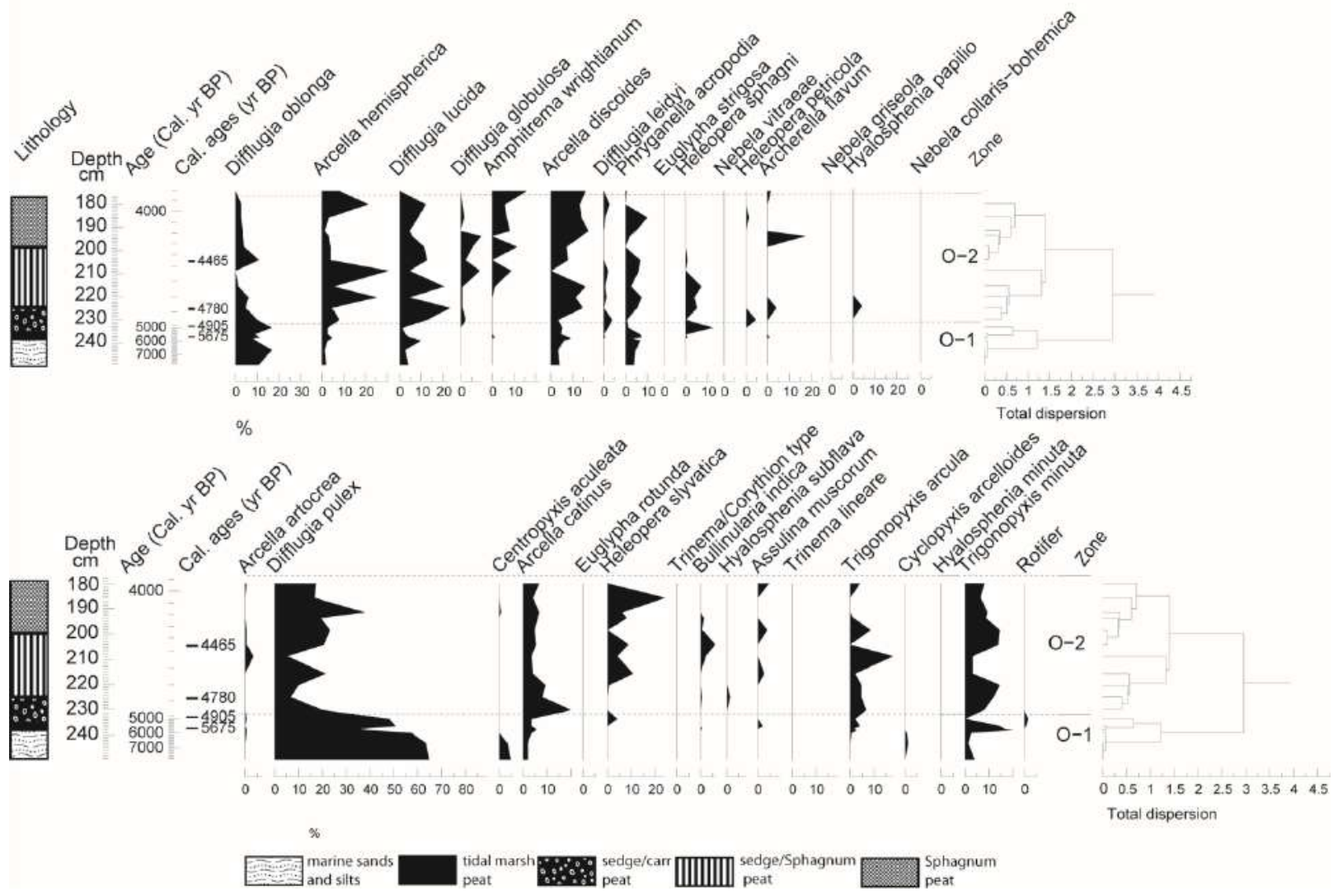

Figure 4 The fossil testate amoeba community representative for the transition between the marine and terrestrial environment at the OFL site, James Bay (Canada). The assemblage zonation was conducted on statistically significant clusters according to CONISS (Bennett, 2007)

\section{Results}

\subsection{Chronostratigraphy}

Table 1 and table 2 show the radiocarbon age measurements that circumscribe the stratigraphic transition between marine and freshwater environments. In addition to these age measurements, we used additional ages from Pendea (2011) to pro- duce age-depth models for both the OFL and W55 core (Fig. 2 and 3). Although the additional age measurements used in the models are representative for the upper part of the cores that are not discussed in this paper, the age-depth modelling performs better when it uses age measurements across the entire core. 
The earliest part of the OFL peatland development (5700 - 4900 cal yr BP) was characterized by low rate of sediment accumulation (Fig. 2). The model shows near constant accumulation rates between 4900 cal yr BP and present. For the W55 peatland, sedimentation rates were low between 6400 and 4000 cal yr BP, but increase significantly thereafter (Fig. 3).

\subsection{Testate amoebae assemblages}

We analysed 74 samples from the OFL core and 77 samples from the W55 core. A minimum of 150 specimens were counted in each sample, as suggested by Booth (2007). Testate amoeba species were identified to the lowest taxonomic level possible, resulting in 46 different species identified throughout the OFL peat core and 42 different taxa for the W55 peat core. A photo collection of some of the commonly observed testate amoebae species from both peat cores is presented in Plate 1. Percent relative abundance of testate amoebae was plotted against depth (cm) and age (cal yr BP) in Fig 4 and Fig 5, using Psimpoll 4.27 program (Bennett, 2007) for both the OFL and W55 peat core, respectively.

\subsubsection{OFL core testate amoeba zonation}

Zone O-1 (5900 - $4900 \mathrm{cal}$ yr BP)

The O-1 zone (Fig. 4) consists mainly of Difflugia pulex, which ranges from $40-65 \%$ abundance in this zone. Other important taxa are Trigonopyxis minuta (3-20\%), Difflugia oblonga (8-16\%), Difflugia lucida (2-10\%), and Heleopera sphagni (0-10\%). Several other taxa, including Arcella artocrea, Centropyxis aculeata, Heleopera sylvatica, Bullinularia indica, Assulina muscorum, Trigonopyxis arcula, Cyclopyxis arcelloides, Arcella hemispherica, Amphitrema wrightianum, Difflugia leidyi, Heleopera petricola, and Archerella flavum are present in an abundance of $5 \%$ or less.

Zone O-2 (4900 - $3900 \mathrm{cal}$ yr BP)

Zone $\mathrm{O}-2$ is characterized by a fluctuating abundance of Difflugia pulex, with values ranging between 5 and 35\%. Other important taxa are Arcella catinus (5-20\% abundance), Arcella emispherica (5$30 \%)$, Heleopera sylvatica (0-25\%), Difflugia lucida (5-25\%), Arcella discoides (0-20\%) and Trigonopyxis arcula (0-20\%). Taxa that are somewhat more irregular in frequency are Archerella flavum (1-20\%), Trigonopyxis minuta (5-15\%), Amphitrema wrightianum (8-10\%), Phryganella acropodia (2-10\%), and Difflugia oblonga (2-10\%). There are several minor taxa that display an abundance of $5 \%$ or less including Bullinularia indica, Assulina. Muscorum, Difflugia globulosa, Arcella artocrea, Difflugia leidyi, Heleopera petricola, and Hyalosphenia papilio.

\subsubsection{W55 testate amoebae zonation}

Zone $W-1(6500-5000 \mathrm{cal}$ yr BP)

The earliest zone of the W55 peat core (Fig 5) is characterized by the dominance of Difflugia pulex, which reaches $20-50 \%$ abundance. Other significant taxa are Difflugia oblonga (5-37\%), Archerella flavum (5-35\%), Phryganella acropodia (5-15\%), Heleopera sylvatica (maximum 10\%) and Difflugia globulosa (maximum 10\%). Minor taxa with abundance ranging below $5 \%$ are Arcella catinus, Trinema corythion type, Hyalosphenia subflava, Trigonopyxis minuta, Arcella hemispherica, Difflugia globulosa, Heleopera sphagni, and Nebela vitraeae.

Zone $W-2(5000-4200 \mathrm{cal}$ yr BP)

Zone W-2 is dominated by Archerella flavum with an abundance ranging from 48 to $65 \%$. Difflugia pulex decreases in abundance from $50 \%$ in Zone W1 to $4 \%$ in W-2. Other important taxa are $A m$ phitrema wrightianum (8-15\% abundance), Heleopera sylvatica (0-10\%), Assulina muscorum (3$10 \%)$, and Difflugia oblonga (2-12\%). Taxa that are minor ( $<5 \%)$ and/or infrequent are Arcella artocrea, Arcella catinus, Trigonopyxis arcula, Trigonopyxis minuta, Arcella hemispherica, Difflugia lucida, Arcella discoides, Phryganella acropodia, Nebela vitraeae, Heleopera petricola, and Nebela griseola.

\subsection{Depth-to-Water table (DWT) reconstruction}

\subsubsection{The OFL peatland}

The testate amoeba-based palaeohydrological reconstruction of the OFL peatland (Fig. 6) shows a DWT that is somewhat more variable than that of the W55 site. Prior to the stratigraphic transition from marine to terrestrial environments, the DWT was small $(\approx 6-8 \mathrm{~cm})$. During the shift from marine 
clays to freshwater peat (5800 and 5600 cal yr BP) the DWT shows a marked increase, amounting to a water table drawdown of up to $20 \mathrm{~cm}$. This surface drying was brief and the peat surface returned to wetter conditions after $5500 \mathrm{cal}$ yr BP.

W55 core, Testate amoeba assemblages, James Bay, Qc
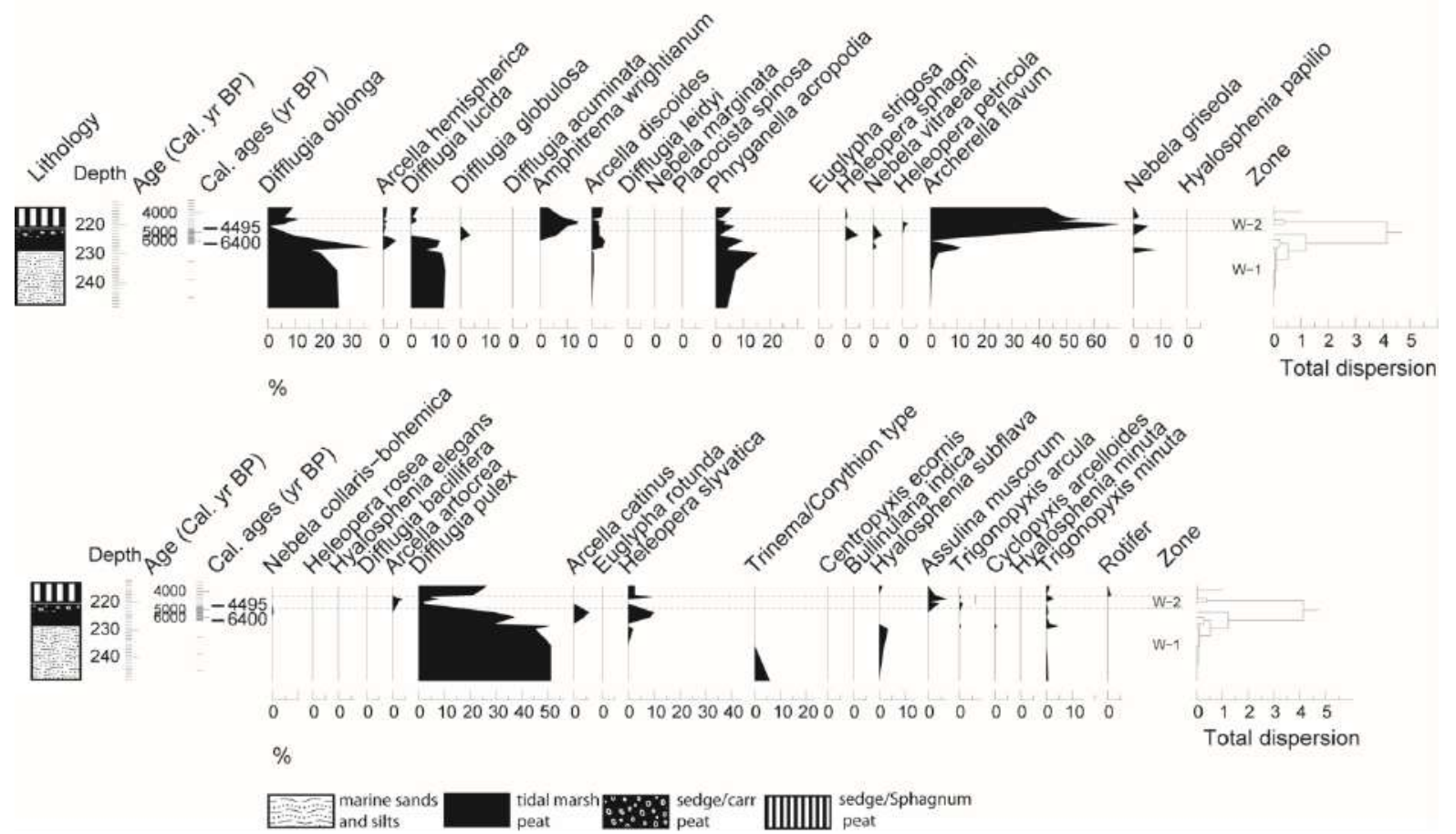

Figure $\mathbf{5}$ The fossil testate amoeba community representative for the transition between the marine and terrestrial environment at the OFL site, James Bay (Canada). The assemblage zonation was conducted on statistically significant clusters according to CONISS (Bennett, 2007)

\subsubsection{The $W 55$ peatland}

The palaeohydrological reconstruction of the W55 peatland (Fig. 7) shows a less fluctuating DWT pattern than the OFL core. During the marine and tidal stages of this site (prior to $6450 \mathrm{cal} \mathrm{yr} \mathrm{BP}$ ), the testate amoeba assemblages indicate, as expected, high water tables with water pooling at the surface. The testate amoeba assemblages retrieved from tidal to freshwater transitional sediments (6450 6200 cal yr BP) indicate a marked but brief water table drawdown at the site. The DWT increases again after $6000 \mathrm{cal}$ yr BP and remains relatively stable during the early freshwater phase of the site.

\section{Discussion}

The utility of testate amoeba as tracers of glacio-isostatic rebound processes

Glacio-isostatic processes are large-scale vertical movement of tectonic plates in response to glacial loading and unloading. The most dramatic effects of these processes are illustrated by shoreline displacement in former glacial regions that underwent marine transgressions. In the James Bay region of northeastern Canada, the postglacial vertical isostatic adjustment totals over $300 \mathrm{~m}$ and this process was marked by a continuous marine regression that is still underway. The importance of this shoreline displacement cannot be understated as ecosystems and people have been continuously affected by dramatic change (Pendea et al., 2010; Pendea, 2011). It follows therefore that our ability to understand these large-scale landscape changes and their impact in the future depends, to a large degree, on precise reconstruction on timing and rate of change of shoreline displacement.

Research on isostatic coastline has concentrated on two aspects. The first aspect is the reconstruction of isolation stratigraphy, that is, the sedimentary sequence associated with the transition from marine 
to terrestrial environments. The second research focus is the precise dating of the isolation event, defined as the period of time when the newly emerged landscape was isolated from the marine waters. Both these research objectives require proxy methodologies that are able to reconstruct events long past.

\section{OFL core-WAPLS (2 component)}

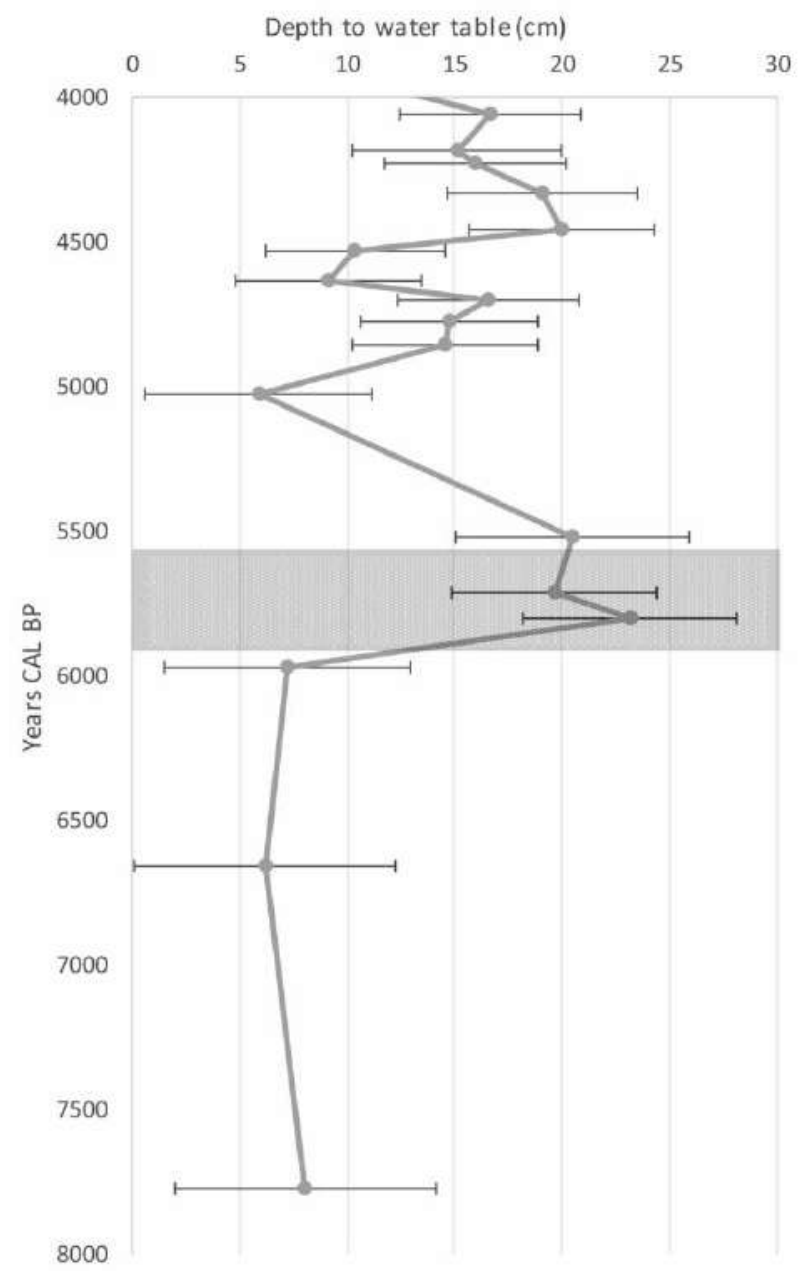

Figure 6 Testate-amoeba inferred water table depths for the OFL core (James Bay, Canada) using the WA-PLS model transfer function. The shaded interval represents the stratigraphic transition between marine and freshwater environments

In Canada, many studies used fossil marine mollusc shells to determine the position of the coastline at any given time and radiocarbon dating of the same shells to determine the shoreline displacement chronology (e.g., Hardy, 1977; Allard and Seguin, 1985; Lajeunesse and Allard, 2003 a, b). The main problem with this approach is related to the relatively large potential errors in reconstruction and dating of palaeo-sea levels.

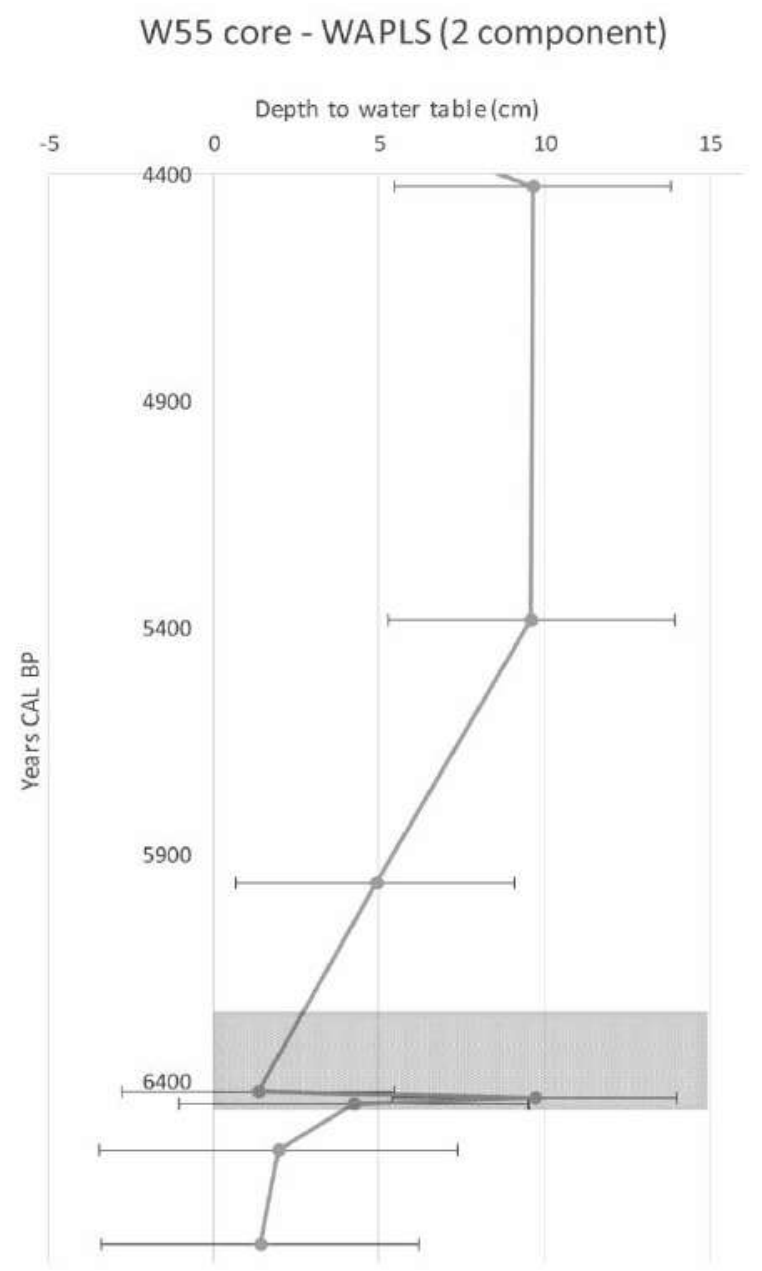

Figure 7 Testate-amoeba inferred water table depths for the W55 core (James Bay, Canada) using the WA-PLS model transfer function. The shaded interval represents the stratigraphic transition between marine and freshwater environments

Mollusc species that are commonly dated in the James Bay region, such as Macoma calcarea, can be found in shallow waters but also has been trawled from depths as great as $300 \mathrm{~m}$ on the continental shelf of Baffin Island (Aitken and Fournier, 1993). In such a case, the potential error in determining the vertical position of a coastline can be as high as 300 $\mathrm{m}$. These shells have also been radiocarbon dated to provide timing for the reconstructed sea level curves. However, the inorganic carbon present in these shells can severely overestimate the actual 
age of the shells, which in James Bay can be by more than 1000 years (Dyke et al., 2003; McNeely et al., 2006).Other studies such as Saulnier-Talbot and Pienitz, (2001), Miousse et al. (2003), and Fedje et al. (2018) have used diatom assemblages to reconstruct shifts in salinity related to the transformation of bays into coastal lakes and dating of organic remains associated with these shifts. This approach represents a major improvement as it avoids the large chronological errors associated with the reservoir effects in mollusc shells. However, the diatominferred salinity shifts are only representative for the isolation event if the residual salinity left in the newly formed lakes is immediately eliminated through drainage. If that is not the case, the marine-specific diatom assemblage will continue to subsist in the sedimentary record and thus underestimate the age of the isolation event.

A third approach was proposed by Pendea et al. (2010), who used pollen, spores and marine plankton fossils to reconstruct tidal environments as representative for the mean position of the coastlines. They also dated plant macrofossils from these environments, which were not affected by the reservoir effect. Although this methodology avoids many of the issues characterizing the other two approaches, it brings in a new challenge related to pollen taphonomy and dispersal. Pollen and spores preservation in sediments depends of the fossilisation environment and some pollen types do not preserve well in environments with frequent change in moisture such as tidal environments. Pollen and spores can also be dispersed over a large area and thus it can be difficult to relate a certain pollen assemblage with a specific location.

In this study, we proposed the use of testate amoeba as markers of change to soil hydrology due to isostatic uplift. The use of testate amoeba in sea level studies has already been demonstrated by Gehrels et al. (2001) in UK saltmarshes, who quantified species preferences for various levels of tidal flooding. However, most research agree that testate amoeba are excellent indicators of soil hydrological regime because assemblages respond very quickly to changes in water table depth (Mitchell et al., 2007). Indeed, our results show a sharp fall in water table depth within the marine/terrestrial stratigraphic sequence most probably related to land uplift and subsequent seaward soil and surface drainage. The unambiguous record of water table drawdown in both cores corresponds well with the palaeoecological record of Pendea et al. (2010), who used pollen, spores and dynoflagellate cysts to reconstruct coastal emergence at the same sites. In their study, however, the reconstructed emergence interval is longer perhaps due to the fact that the palaeoecological proxies used to pinpoint emergence are indicative of the resulting ecosystems rather than the physical retreat of water from any given location. In this sense, testate amoeba help further constrain the emergence time and thus increase the precision of reconstructed sea level curves.

\section{Conclusions}

Our study demonstrates the potential for testate amoeba analysis in tracing coastal change related to isostatic rebound. Testate amoeba complement other palaeoecological indicators used previously (e.g., pollen, spores, marine and freshwater plankton), but may be more sensitive to the actual sea level fall by recording the local water table drawdown. However, future studies need to concentrate on calibrating the testate amoeba's ecological responses to sea level change via other parameters (e.g., salinity, hydroperiod). As Mitchel et al. (2008) pointed out, the reliability of this method depends to a large degree to a better understanding of taphonomy and ecological affinities of these microfossils.

\section{Acknowledgements}

We would like to thank Dr. Robert K. Booth from Lehigh University for his valuable assistance with the use of DWT transfer function for testate amoebae in peatlands of North America. We are also indebted to the Wemindji Cree First Nation for their support and fieldwork assistance. F. Pendea would like to thank fellow fieldworker Jesse Sayles for his friendship and assistance during the fieldwork season of 2007. 
Plate 1 Photo collection of commonly observed testate amoebae for OFL and W55 peat cores, James Bay, Québec
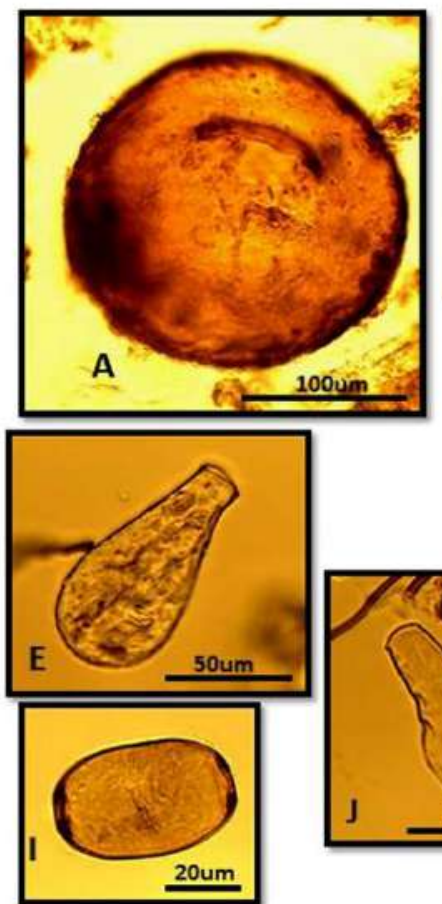

A) Bullinularia indica B) Euglypha spinosa type C) Trigonopyxis arcula

D) Arcella discoides type E) Nebela wailesi type

F) Assulina muscorum

G) Hyalosphenia papilio
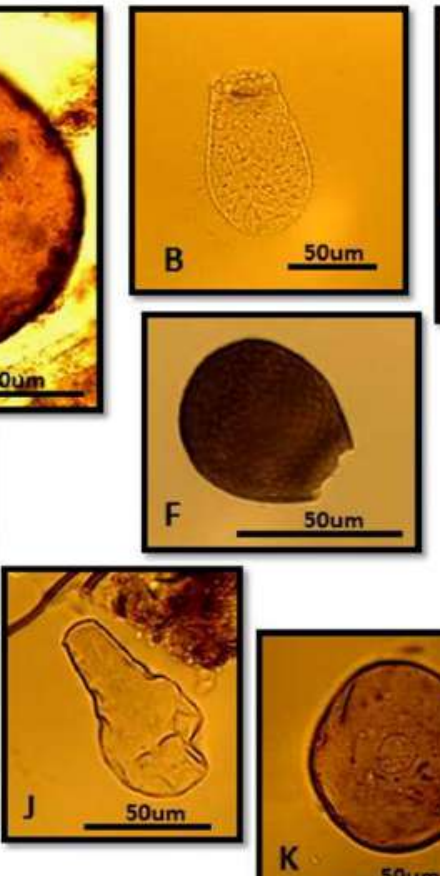

H) Arcella artocrea 1) Archerella flavum J) Hyalosphenia elegans K) Arcella hemispherica L) Amphitrema wrightianum

M) Nebela collaris-bohemica type N) Nebela militars type
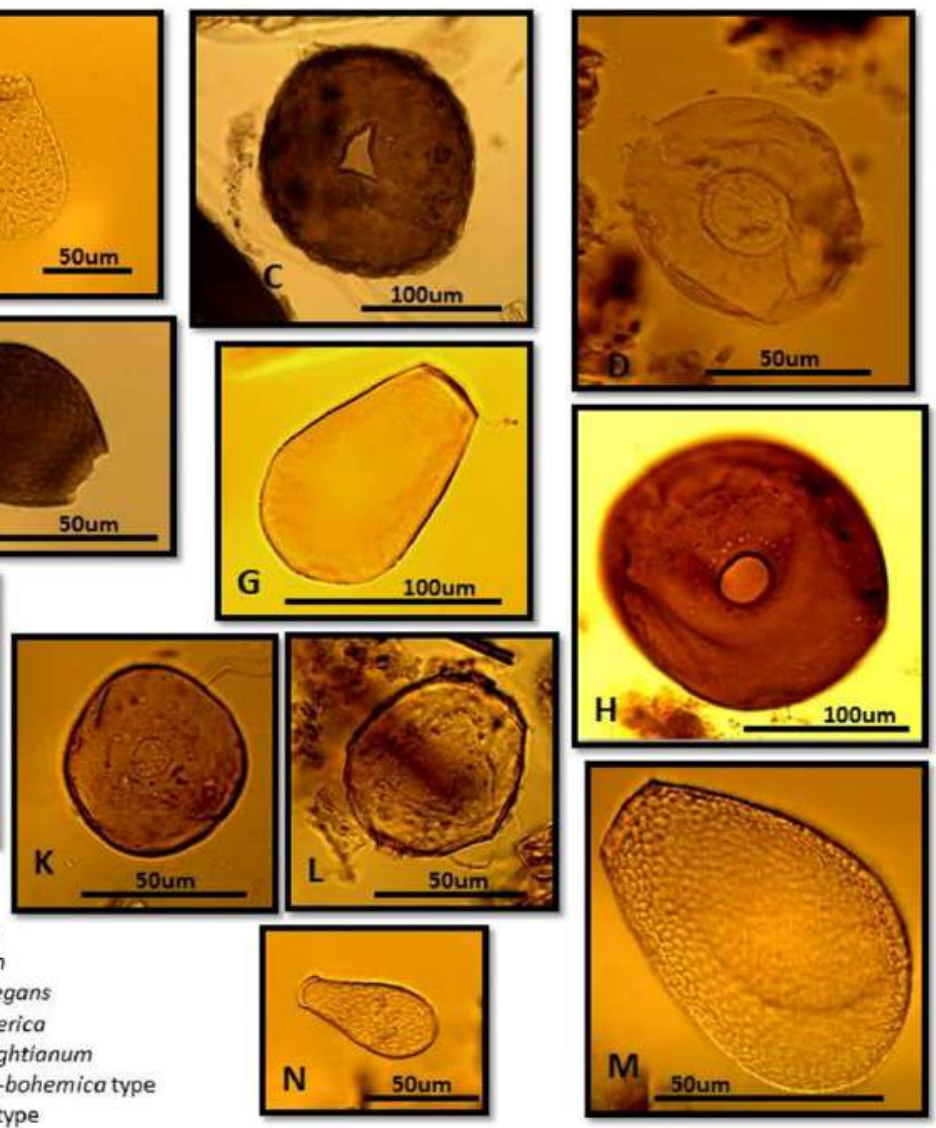

\section{References}

Aitken AE, Fournier J. 1993. Macrobenthos communities of Cambridge, McBeth and Itirbilung Fiords, Baffin Island, Northwest Territories, Canada. Arctic, 46: 60-71.

Allard M, Seguin MK. 1985. La déglaciation d'une partie du versant hudsonien des rivières Nastapoka, Sheldrake et à l'Eau Claire. Géographie physique et Quaternaire, 39: 13-24.

Amesbury MJ, Mallon G, Charman DJ, Hughes PDM, Booth RK, Daley TJ, Garneau M. 2013. Statistical testing of a new testate amoebae-based transfer function for water table depth reconstruction on ombrotrophic peatlands in north-eastern Canada and Maine, United States. Journal of Quaternary Science, 28(1): 27-39.

Booth RK. 2002. Testate amoebae as palaeoindicators of surface-moisture changes on Michigan peatlands: modern ecology and hydrological calibration. Journal of Paleolimnology, 28: 329-348.

Booth RK. 2007. Testate amoebae as proxies for mean annual water-table depth in Sphagnum dominated

peatlands of North America. Journal of Quaternary Science, 23(1): 43-57.

Booth RK, Zygmunt JR. 2005. Biogeography and comparative ecology of testate amoebae inhabiting Sphagnum-dominated peatlands in the Great Lakes and Rocky Mountain regions of North America. Diversity and Distributions, 11: 577-590.

Booth RK, Sullivan ME. 2007. Testate amoebae as palaeohydrological proxies in peatlands. Earth \& Environental Science Department. Lehigh University. 35p.

Booth RK, Lamentowicz M, Charman DJ. 2010. Preparation and analysis of testate amoebae in peatland palaeoenvironmental studies. Mires and Peat, 7(2): 1-7.

Bennett KD. 2007. Psimpoll and Pscomb programs for plotting and analysis. Available online at University of Cambridge, Cambridge, UK.

URL:http://www.chrono.qub.ac.uk/psimpoll/psimpoll. html

Charman DJ. 2001. Biostratigraphic and palaeoenvironmental applications of testate amoebae. Quaternary science reviews, 20: 1753-1764. 
Crins WJ, Gray PA, Uhlig PWC, Wester MC. 2009. The ecosystems of Ontario, part 1: ecozones and ecoregions. Ontario Ministry of Natural Resources, Peterborough Ontario, Inventory, Monitoring and Assessment, 1-71.

Dyke AS, Moore A, Robertson L. 2003. Deglaciation of North America. Open File 1574. Geological Survey of Canada.

Dyke AS. 2004. An outline of North American Deglaciation with emphasis on central and northern Canada. Geological survey of Canada, 371-406.

Fedje D, McLaren D, James TS, Mackie Q, Smith NF, Southon JR, Mackie AP. 2018. A revised sea level history for the northern Strait of Georgia, British Columbia, Canada. Quaternary Science Reviews, 192: 300-316.

Gehrels WR, Roe HM, Charman DJ. 2001. Foraminifera, testate amoebae and diatoms as sea-level indicators in UK saltmarshes: a quantitative multiproxy approach. Journal of Quaternary Science, 16: 201-220.

Glaser PH, Hansen BCS, Siegel DI, Reeve AS, Morins PJ. 2004. Rates, pathways and drivers for peatland development in the Hudson Bay Lowlands, northern Ontario,Canada. Journal of Ecology, 92: 1036-1053.

Hardy L. 1977. La déglaciation et les épisodes lacustre et marin sur les versants de la partie québécoise des basses terres de la baie de James. Géographie Physique et Quaternaire, 31: 261-273.

Haslett J, Parnell A. 2008. A simple monotone process with application to radiocarbon-dated depth chronologies. Journal of the Royal Statistical Society Series C-Applied Statistics, 57: 399-418.

Hillaire-Marcel C. 1980. Multiple component post-glacial emergence, Eastern Hudson Bay, Canada. In: Morner, NA. (ed.): Earth Rheology, Isostasy and Eustasy. Wiley, Toronto, pp. 215-230.

Juggins S. 2003. C2 User guide. Software for ecological and paleoecological data analysis and visualization. University of Newcastle: Newcastle upon Tyne, UK, 69.

Lajeunesse P, Allard M. 2003a. Late Quaternary deglaciation, glaciomarine sedimentation and glacioisostatic recovery in the Rivière Nastapoka Area, Eastern Hudson Bay, Northern Québec. Géographie physique et Quaternaire, 57: 65-83.

Lajeunesse P, Allard M. 2003b. The Nastapoka drift belt, eastern Hudson Bay: implications for a stillstand of the Québec-Labrador ice margin in the Tyrrell Sea at 8 ka BP. Canadian Journal of Earth Sciences, 40: 6576.

Lamarre A, Magnan G, Garneau M, Boucher E. 2013. A testate amoebae-based transfer function for paleohydrological reconstruction from boreal and subarctic peatlands in northeastern Canada. Quaternary International, 306: 88-96.

McNeely R, Dyke AS, Southon JR. 2006. Canadian marine reservoir ages: Preliminary data assessment. Open File 5049. Geological Survey of Canada.

Miousse L, Bhiry N, Lavoie M. 2003. Isolation and waterlevel fluctuations of Lake Kachishayoot, Northern Québec, Canada. Quaternary Research, 60: 149-161.

Mitchell EAD, Charman DJ, Warner BG. 2007. Testate amoebae analysis in ecological and paleoecological studies of wetlands: past, present and future. Biodiversity conservation, 17: 2115-2137.

Parnell AC, Haslett J, Allen JRM, Buck CE, Huntley B. 2008. A flexible approach to assessing synchroneity of past events using Bayesian reconstructions of sedimentation history. Quaternary Science Reviews, 27: 18721885.

Pendea IF, Costopoulos A, Nielsen C, Chmura GL. 2010. A new shoreline displacement model for last $7 \mathrm{ka}$ from eastern James Bay, Canada. Quaternary research, 73: 474-484. Pendea IF, Chmura GL. 2012. A high resolution record of carbon accumulation rates during boreal peatland initiation. Biogeosciences, 9: 2711-2717.

Pendea I.F. 2011. Mid to late Holocene coastal landscape change in eastern James Bay. PhD Thesis, Department of Geography McGill University, 154 p.

Reimer PJ, Baillie MGL, Bard E, Bayliss A, Beck JW, Bertrand CJH, Blackwell PG, Buck CE, Burr GS, Cutler KB, Damon $P E$, Edwards RL, Fairbanks $G$, Friedrich $M$, Guilderson TP, Hogg AG, Hughen KA, Kromer B, McCormac G, Manning S, Bronk Ramsey C, Reimer RW, Remmele S, Southon JR, Stuiver M, Talamo S, Taylor FW, van der Plicht J, Weyhenmeyer CE. 2004. IntCal04 terrestrial radiocarbon age calibration 0-26 cal kyr BP. Radiocarbon, 46: 1029-1058.

Saulnier-Talbot É, Pienitz R. 2001. Isolation au post-glaciaire d'un bassin côtier près de Kuujjuaraapik Whapmagoostui, en Hudsonie (Québec): une analyse biostratigraphique diatomifère. Géographie physique et Quaternaire, 55: 63-74.

Talma AS, Vogel JC. 1993. A simplified approach to calibrating 14C dates. Radiocarbon, 35: 317-322.

van Bellen S, Mauquoy D, Payne RJ, Roland TP, Daley TJ, Hughes PDM, Loader NJ, Street-Perrott FA, Rice EM, Pancotto VA. 2014. Testate amoebae as a proxy for reconstructing Holocene water table dynamics in southern Patagonian peat bogs. Journal of Quaternary Science, 29(5): 463-474.

Woodland WA, Charman DJ, Sims PC. 1998. Quantitative estimates of water tables and soil moisture in Holocene peatlands from testate amoebae. The Holocene, 8(3): 261-273. 